\title{
Ukrainian Government Bureaucracy: Benefits and Costs for the Society
}

\author{
Victor Fedosov $^{1}$, Tetiana Paientko ${ }^{1}$ \\ ${ }^{1}$ Kyiv National Economic University, named after Vadym Hetman, Kyiv, Ukraine \\ Correspondence: Tetiana Paientko, Kyiv National Economic University, Named After Vadym Hetman, Kyiv, Peremohy \\ Avenu 54/1, Ukraine.
}

Received: April 17, 2017

doi:10.11114/bms.v3i2.2358

Accepted: May 11, $2017 \quad$ Online Published: May 15, 2017

URL: https://doi.org/10.11114/bms.v3i2.2358

\begin{abstract}
Government bureaucracy efficiency, and its attending cost for society, is one of the gravest issues currently facing Ukraine. The low efficiency of Ukrainian government bureaucracy is caused by a merger of bureaucracy, political power, and large, manipulating business interests. As a result, Ukraine faces a significantly depressed economy, a high level of corruption, low property rights protection, and a pervasive lack of trust in the government in general. In order to understand the true costs and benefits of government bureaucracy for the Ukrainian society, a methodology of calculating bureaucracy specifically for Ukraine was developed. Previously unused indicators were added to provide greater accuracy. The inefficiency of Ukrainian government bureaucracy was determined categorically. Paths to the improvement of Ukrainian government bureaucracy efficiency were suggested.
\end{abstract}

Keywords: bureaucracy, efficiency, costs, benefit, corruption, marginal costs

\section{Introducation}

The ideological transformation of Ukrainian society from administration-by-fiat to a democratic system demanded intensive institutional reforms be made. Often this situation becomes the basis for the creation of new government organizations in addition to those already in existence. This in turn raises the costs of maintaining government bureaucracy, increasing the fiscal burden on society. However, the effect of such an increase in the cost of maintaining that larger bureaucracy is not always accompanied by benefits hoped for by the society.

One of the peculiarities of the modern Ukrainian government bureaucracy development was inherited from the Soviet period. Government bureaucracy then was under the control of politicians, and its main role was to implement Communist Party ideology. Unlike other countries within the Socialist camp, modern Ukrainian bureaucracy inherited traits not only from the bureaucracy of the socialistic period, but also from the bureaucracy of Imperial Russia, still being manifested in Ukraine even after a number of attempts to carry out democratic transformations. Another feature of the Ukrainian bureaucracy began to take shape after the collapse of the Soviet Union in the early 1990s. In that time Ukraine experienced an initial accumulation of capital stage, which took place without a proper legal basis. As a result, state ownership fell into the hands of a limited circle of people who then privatized state assets, and significantly, political power.

The desire for great social and political change then grew into the Orange Revolution in 2004, but the expectations of society were subsequently left unfulfilled. The changes that were needed in the area of government bureaucracy simply did not occur. Instead, a new stage of property redistribution and entrenchment of oligarchic clans and power took place. Ever since then, the leaders of these groups directly or indirectly have had unlimited access to the economic resources of the state, ensuring a constant growth of wealth, stashing money abroad through offshore accounts, which contributed nothing to the development of Ukraine's economy and left its competitiveness in the modern world floundering. The loss of confidence in the leaders of the Orange Revolution became the basis of Viktor Yanukovych coming to power, resulting in a ruling party vertical and strict distribution of government posts to those who belonged to that party. The so-called Revolution of Dignity in 2013-2014 had as its goal the destruction of this system. However, the first government of A.Yatsenyuk showed that the ruling political class would continue to support the traditional "policy bureaucracy - big business" modus operandi. Again, access to key government positions was closed to those who do not belong to nor support this system. The reality in Ukraine continues to show past patterns of behavior with an extensive co-mingling of bureaucracy and business, maintaining the ineffectiveness of governance, and especially, active cooperation with the political elite, often basing major government decisions on the selfish vested interests of that 
elite. The system of "policy - bureaucracy - big business" turns out to not only be seemingly impossible to replace or modify, but extremely expensive and inefficient in its service to the citizens of Ukraine. Despite all the lip service paid to allegiance to western democratic values and desires to join the European Union, this merger of political power, government, and big business does not contribute in any way to Ukraine's social and economic development, but rather, is denying the chance for future generations of Ukraine to live in a truly democratic country. Regarding the cost of government bureaucracy to the Ukrainian nation, the direct costs of taxpayer funds for its upkeep is not the only ramification, but also the losses occurring indirectly as a result of ineffective government bureaucracy. This is why the main object of the article to show how much Ukrainian society looses because of unefficient government bureaucracy.

\section{Literature Review}

A complete study of bureaucracy was conducted by the German sociologist, M. Weber. He is one of the few who spoke of bureaucracy with kind words, and even idealized it. The most important benefit of the bureaucracy, he thought, was governance competence based on knowledge. M. Weber considered the effective activities of a government administrative apparatus to be a necessary condition for the rational organization of the social and economic reality in general (Weber, 1922). His publications became the starting point for the development of independent concepts of bureaucracy. Publications of recent years about theories of bureaucracy development are different, but mainly are within a single concept. Part of this publication is devoted to the historical aspect of the development of bureaucracy, its relationship with the formation of modern models of societal functioning (F. Monnier \& G. Thuillier, 2010, D. Ungureanu, 2012). The turning of the $20^{\text {th }}$ to the 21 st century in Ukraine was marked by an aggravation of the problems caused by government bureaucracy inefficiency. This caused a growth of interest in institutional approaches, where economists have paid heightened attention to the principles of good governance, as reflected in the publications S. Knack and P. Keefer (1994), D. Rodrick (1999), D. Kaufmann (2004) etc.

A large number of Ukrainian publications in recent years have been devoted to the political aspect of bureaucratic functions and its role in social and political life (O. Tsapko, 2012, O. Batrymenko, 2009, M. Doroshko, 2008, V. Puhach, 2006) etc. Part of this research is focused on the evaluation of bureaucracy effectiveness in the public sector from the point of view of public choice rationality; and to identify the causes of the bureaucratic crisis and its consequences for the nation.

The problem of measuring the effectiveness of government bureaucracy began to be actively explored by scholars in the late $20^{\text {th }}$ - early 21 st centuries. Ideas of bureaucracy effectiveness being measured are based mainly on macroeconomic indicators of a nation's success in development (R. Hall \& C. Jones, 1999, P. Evans \& JE. Rauch, 1999, D. Dollar \& A. Kraay, 2003). The development of common indicators of government bureaucracy effectiveness are presented in publications by D. Kaufmann, A. Kraay \& P. Zoido-Lobaton, 1999, S. Knack, M. Kugler \& N. Manning, 2005, AD Williams \& A. Siddique, 2007. A number of reports of government bureaucracy efficiency evaluations, the impact on economic development, and the level of corruption in various countries were published by the International Monetary Fund. International comparisons of bureaucracy efficiency in terms of education, health, justice, and administration of taxes annually were published by the OECD. However, a unified government bureaucracy valuation of cost to society and effectiveness of government bureaucracy functions for individual countries has still not been developed.

The purpose of this article is an analysis of Ukrainian government bureaucracy costs, an assessment of its effectiveness, and a cost-benefit analysis of government bureaucratic activity for the nation.

\section{Method}

Arriving at an accurate estimate of the costs of a functioning bureaucracy is a complex problem that is caused by the necessity of the use of quantitative and qualitative indicators, as well as a combination of cost and benefit indicators. On the basis of only an absolute amount of government bureaucracy financing and pace of growth it is not possible to draw conclusions about its cost to society. Situations where a growing number of officials and increasing expenditures will be accompanied by a corresponding growth of competitiveness of the national economy and increase in the general welfare of society are not excluded. According to Max Weber this effect is possible when an impersonal functioning bureaucracy is present, and which guarantees protection from arbitrary actions by a state. That is why government bureaucracy should have as its principle function to be an instrument for the good of the society it serves, and not turned into an autonomous force, usurping power for its own ends. Therefore, increases and decreases of government bureaucracy and the attending cost should be justified, that is matched by a corresponding beneficial effect for the society. Often such statements are taken too literally and have become a basis for reducing the cost of government bureaucracy, or number of officials, in order to have economic growth and an increase in the general welfare of a society.

A peculiarity of government bureaucracy is that it is possible to evaluate the effectiveness of its activity at any particular stage of society, but it is impossible to predict exactly how these figures would change depending on only quantitative changes (e.g, the number of officials or associated costs). These changes can be positive when society respects 
government and is prepared to collaborate with it, as described in the articles of K. Murphy, M. Shleifer \& R. Vishny (1993) and G. Richardson (2008). In cases of a negative attitude to power and disbelief that the arrival of a new government could improve life in a society, because of a long history of failure to substantiate election promises, the impact of changes in the number and cost of financing government bureaucracy becomes unpredictable. This situation was described in the publications of T. Rudolph (2009) and B. Caplan (2007).

Therefore, an evaluation of bureaucracy effectiveness requires an assessment of the costs and benefits of bureaucracy activity. If more benefits are provided at a stable cost, the efficiency will be higher. When estimating the cost of government bureaucracy from a society's point of view, it is important to bear in mind that the funds allocated to finance government bureaucracy are sourced from taxpayers. It is therefore natural that an increase in the cost of bureaucracy should be accompanied by a growth in social benefits, albeit with some time lag. The effects from reducing the cost of bureaucracy are more debatable. If this reduction is associated with a policy of deficit reduction, it must also consider the ultimate effect on a society. That is, the efficiency of bureaucracy to society should not be reduced because the tax burden will be the same or even increased.

A difficulty in assessing bureaucracy effectiveness is caused by the lack of a common approach to defining the essence of the bureaucracy efficiency, and therefore the choice of indicators. The possibilities of using mathematical methods are also limited, because the sample data is small, and in Ukraine systematized information on government bureaucracy financing is only available from 2007.

International organizations are developing methods for assessing the value and effectiveness of the bureaucracy and periodically publish the results. In 2006 the European Central Bank published working materials ${ }^{1}$ that became the basis for evaluating the effectiveness of government bureaucracy for new EU member states and countries with emerging economies. The basis of the methodology combined standard criteria (R. Musgrave's criteria) and alternative indicators (Table. 1), on which the PSP index is calculated (Public sector performance).

Table 1. Indicators of Government Bureaucracy Efficiency

\begin{tabular}{|c|c|c|c|}
\hline Alternative indicators & & Standard indicators & \\
\hline Corruption & & Redistribution & Gini Ratio \\
\hline Red tape & & & Inflation (recent 10 years) \\
\hline Rule of law & Administration & Stability & $\begin{array}{l}\text { Stability in GDP growth (10 } \\
\text { years) }\end{array}$ \\
\hline $\begin{array}{l}\text { Shadow economy } \\
\text { Quality of science } \\
\text { Infant mortality } \\
\text { Remaining life expectancy }\end{array}$ & $\begin{array}{l}\text { Education } \\
\text { Health care }\end{array}$ & Economic development & $\begin{array}{l}\text { Unemployment (recent } 10 \\
\text { years) } \\
\text { Real GDP growth in recent } 10 \\
\text { years }\end{array}$ \\
\hline
\end{tabular}

Source: created by authors

The use of this index is valid for analyses between countries, which goes beyond the scope of this article. However, some indicators can be used to assess efficiency of the bureaucracy for particular countries, including Ukraine. Based on previous research done in western countries and taking into account the specifics of Ukraine, methods of evaluating the effectiveness of the bureaucracy and its costs to society, the following can be seen:

1. Assessment of the relationship between expenditures to finance government bureaucracy and economic growth. For this purpose, information about total GDP, expenditures to finance the government bureaucracy, the share of these expenditures in the general consolidated budget and GDP was used (Table. 2)

2. Assessment of the relationship of government bureaucracy costs with indicators of economic development. To do this, information about the funding system of public administrations, civil servants and local government officials was obtained, and the share of these expenditures in the consolidated budget and GDP was used (Table. 2). The importance of analyzing these indicators is due to the declaration of the Ukrainian government to pursue a course of fiscal decentralization. The results of analysis reveal how government intentions correspond to reality.

3. Maintenance cost analysis of all executive staff of ministries, both central and regional, and its relationship with economic growth (Table. 3). For this purpose, growth of GDP per capita and indicators of marginal costs were used.

4. Analysis of Ukrainian government bureaucracy expenditures using state development indicators in international rankings (Tables 4-6). The analysis was based on information of the State Treasury Service of Ukraine (public administration expenditures), the State Statistics Service of Ukraine (GDP), National Agency of Ukraine on Civil Service (number of civil servants in state bodies and officials of local governments). All information is contained in the

\footnotetext{
${ }^{1}$ Public Sector Efficiency Evidence for New EU Member States and Emerging Markets 1 by António Afonso 2, 3, Ludger Schuknecht 3 and Vito Tanzi. WORKING PAPER SERIES NO. 581 / JANUARY 2006
} 
public domain, with data available starting in 2007.

5. Conclusions and acknowledgements.

\section{Results}

To start, an assessment of the overall situation of government bureaucracy funding and its effectiveness was given. The assessment is based on the indicators which are presented in Table 1 and the information which is given in the Table. 2. The amount of government bureaucracy funding (expenditures for public administration is the official name of the budget classification) tend to increase, but their share of expenditures and in GDP gradually decreases (Table. 2). The number of people involved in the work of the bureaucracy (civil servants and local government officials) for 2008-2009 and 2012-2013 increased but from 2014 the number is steadily reduced. These uneven trends were caused by repeated changes of state policy. In 2014, a plan to reduce the number of officials, with corresponding reduction in funding, was announced.

It should be noted that fluctuations in the size of the bureaucracy and its funding unevenly correspond with economic and welfare growth during this period. Thus, indicators such as Ginny rate, inflation, GDP growth, and unemployment did not meet the criteria of an effective bureaucracy. In particular, the Ginny ratio in 2007 was 27.01, in 2012 it was 24.74, in 2015 it was 24.01; these trends show a high level of income disparity. When comparing the dynamics of the Ukrainian Ginny ratio with those in developed countries, the situation does not seem too critical. However, for economies like the Ukrainian, in the context of evaluating the effectiveness of government bureaucracy funding, this is not the only important factor. It is necessary also to consider the level of poverty and the share in total income of the $10 \%$ richest and $10 \%$ poorest. In Ukraine, the $10 \%$ richest segment increased in 2015 and almost reached a $25 \%$ share in total income.

The inflation rate in 2007-2009 annually exceeded 10\%, and in 2014 and 2015, growth in the consumer price index was $124.9 \%$ and $143.3 \%$ respectively. Over the past two years, the unemployment level (according to ILO methodology) and the average duration of unemployment has increased, and is growing. As shown in Table 2, there is a nominal GDP increase, but this increase is inflationary. GDP growth calculated in US dollar terms, shows a deep decline in 2009 of $34.9 \%$, further slowdown in 2012-2013, and falls in 2014 and 2015 by 28.1 and $31.3 \%$ respectively.

Thus, the standard Musgrave's indicators of bureaucracy performance indicate low efficiency in Ukraine. As the described situation is prolonged, its consequences are an increasingly negative attitude of society towards government bureaucracy. Most people no longer perceive the government as legitimate, but charging them taxes which are used for an inefficient government bureaucracy, perceived as an unjustified burden. This situation was described by B. Caplan (2007) and E. Weede (1996). This often occurs when political parties have access to a redistribution of public resources because of the politicization of bureaucracy and its fusion with big business.

Even though politicians over the past decade have been talking about the need to strengthen local government and activate fiscal decentralization, the share of local expenditures for financing local bureaucracy has grown slowly, the average growth rate over the period amounting to $2 \%$. If we compare the ratio of civil servants and local government officials, the results do not conform to government guidelines. In 2007, the share of local government officials amounted to $27.16 \%$, in $2012-26.31 \%$, in $2015-23.72 \%$. Instead, an increase of civil servants is continuing contrary to the process of fiscal decentralization.

The management cost per unit in ministries, other central executive bodies, and in regional bodies increased (Table. 3 ). If a general trend of increased costs could be explained by an inflation factor, the increase in costs should be accompanied by an appropriate effect for society. However, during the study period, the management cost growth per unit was not accompanied by a marginal growth in GDP. During the study period, marginal GDP is less than marginal cost, except in 2009.

In addition, there is a very weak correlation between the studied parameters, even considering the fact that calculations were made using a small sample (Fig. 1). 


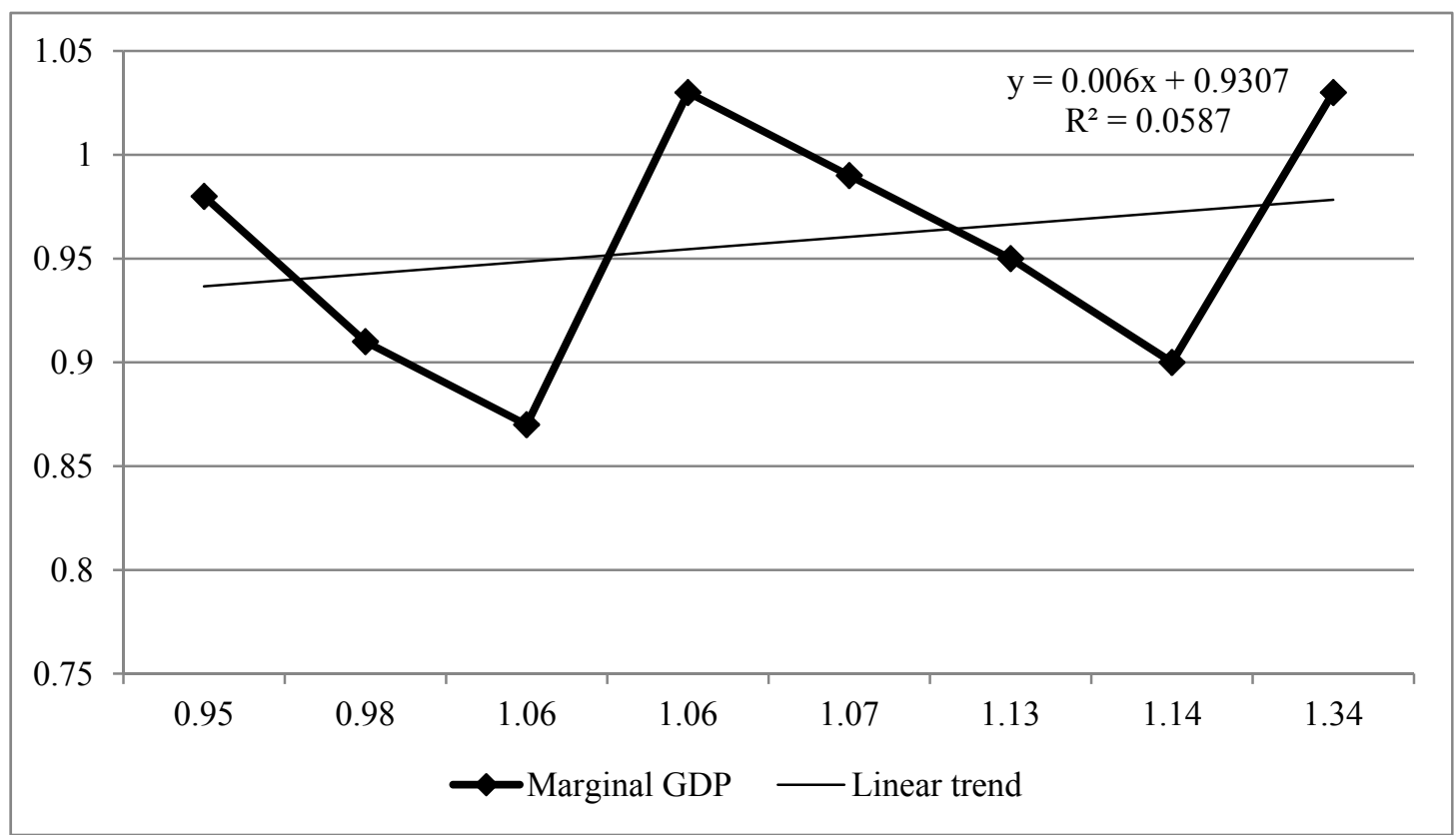

Figure 1. Correlation between marginal GDP and marginal costs per a civil servant

Source: calculated by authors

The absence of a strong correlation between marginal costs of government bureaucracy and marginal GDP indicates that the activity of the bureaucracy in Ukraine is ineffective for the welfare of society. This partly explains the increase in the shadow economy, the reluctance to voluntarily pay taxes, and a growing distrust, not only in a particular government, but to government in general. Thus, the standard Musgrave's indicators prove that Ukrainian government bureaucracy is inefficient, therefore the cost of its maintenance may be regarded by society as a burden. 
Table 2. Sources of Ukrainian Government Bureaucracy Funding in 2007-2015

\begin{tabular}{|c|c|c|c|c|c|c|c|c|c|}
\hline Indicators & 2007 & 2008 & 2009 & 2010 & 2011 & 2012 & 2013 & 2014 & 2015 \\
\hline $\begin{array}{l}\text { Expenditures on } \\
\text { public } \\
\text { administration, } \\
\text { total mln UAH }\end{array}$ & 7442,68 & 10074,49 & 9557,93 & 10773,45 & 11418,13 & 12083,03 & 12794,78 & $\begin{array}{c}12513,9 \\
1\end{array}$ & 14252,6 \\
\hline $\begin{array}{l}\text { State budget, } \\
\text { mln UAH }\end{array}$ & 2814,22 & 3809,82 & 3249,69 & 3550,21 & 3626,73 & 3854,12 & 4300,25 & 4331,89 & 4482,85 \\
\hline $\begin{array}{l}\text { Share of state } \\
\text { budget } \\
\text { expenditures in } \\
\text { total } \\
\text { expenditures, \% }\end{array}$ & 37,81 & 37,82 & 34,00 & 32,95 & 31,76 & 31,90 & 33,61 & 34,62 & 31,45 \\
\hline $\begin{array}{l}\text { Local budgets, } \\
\text { mln UAH }\end{array}$ & 4628,46 & 6264,69 & 6308,24 & 7223,24 & 7791,39 & 8228,9 & 8494,52 & 8182,55 & 9769,75 \\
\hline $\begin{array}{l}\text { Share of local } \\
\text { budgets } \\
\text { expenditures in } \\
\text { total } \\
\text { expenditures, \% }\end{array}$ & 62,19 & 62,18 & 66,00 & 67,05 & 68,24 & 68,10 & 66,39 & 65,39 & 68,55 \\
\hline $\begin{array}{l}\text { Total budget } \\
\text { expenditures, } \\
\text { mln UAH }\end{array}$ & $\begin{array}{c}226054,3 \\
7\end{array}$ & $\begin{array}{c}309203,7 \\
3\end{array}$ & $\begin{array}{c}307399,3 \\
5\end{array}$ & $\begin{array}{c}377842,8 \\
4\end{array}$ & $\begin{array}{c}416853,5 \\
8\end{array}$ & $\begin{array}{c}492434,6 \\
6\end{array}$ & $\begin{array}{c}505843,8 \\
1\end{array}$ & $\begin{array}{c}523125 \\
7\end{array}$ & $\begin{array}{c}679871 \\
4\end{array}$ \\
\hline GDP, mln UAH & 720731 & 948056 & 913345 & 1082569 & 1316600 & 1408889 & 1454931 & 1566728 & 1979458 \\
\hline $\begin{array}{l}\text { Share of } \\
\text { expenditures on } \\
\text { public } \\
\text { administration in } \\
\text { total budget } \\
\text { expenditures, \% }\end{array}$ & 3,29 & 3,26 & 3,11 & 2,85 & 2,74 & 2,45 & 2,53 & 2,39 & 2,10 \\
\hline $\begin{array}{l}\text { Share } \\
\text { expenditures of } \\
\text { public } \\
\text { administration in } \\
\text { GDP, \% }\end{array}$ & 1,03 & 1,06 & 1,05 & 1,00 & 0,87 & 0,86 & 0,88 & 0,80 & 0,72 \\
\hline $\begin{array}{l}\text { The total number } \\
\text { of civil servants } \\
\text { and local } \\
\text { government } \\
\text { officials, person }\end{array}$ & 364263 & 379289 & 384197 & 379283 & 367308 & 372856 & 433269 & 380257 & 351835 \\
\hline $\begin{array}{l}\text { Limit the } \\
\text { number of } \\
\text { employees of } \\
\text { ministries and } \\
\text { other central } \\
\text { executive bodies } \\
\text { and subordinate } \\
\text { territorial bodies, } \\
\text { person }\end{array}$ & 19063 & 19276 & 19296 & 19301 & 19301 & 19052 & 19052 & 19052 & 19052 \\
\hline $\begin{array}{l}\text { GDP growth, } \\
\text { expressed in US } \\
\text { dollar terms (\% } \\
\text { to previous year) }\end{array}$ & $+32,5$ & $+26,1$ & $-34,9$ & $+16,4$ & $+19,6$ & $+7,7$ & $+4,3$ & $-28,1$ & $-31,3$ \\
\hline $\begin{array}{l}\text { The growth of } \\
\text { nominal GDP, } \%\end{array}$ & $+32,5$ & $+31,5$ & $-3,7$ & $+18,5$ & $+21,6$ & $+7,0$ & $+3,3$ & $+7,7$ & $+26,3$ \\
\hline $\begin{array}{l}\text { The growth of } \\
\text { spending on } \\
\text { administration, } \\
\%\end{array}$ & $\ldots$ & $+35,36$ & $-5,13$ & $+12,72$ & $+5,98$ & $+5,82$ & $+5,89$ & $-2,20$ & $+13,89$ \\
\hline
\end{tabular}

Source: calculated by authors, based on data of State Treasury Service and State Statistic Service of Ukraine 
Table 3. The Number of People Employed in Public Administration in Ukraine and their Performance in Productivity 2007-2015

\begin{tabular}{|c|c|c|c|c|c|c|c|c|c|}
\hline Indicators & 2007 & 2008 & 2009 & 2010 & 2011 & 2012 & 2013 & 2014 & 2015 \\
\hline $\begin{array}{l}\text { The total number of } \\
\text { civil servants and local } \\
\text { government officials, } \\
\text { persons }\end{array}$ & 364263 & 379289 & 384197 & 379283 & 367308 & 372856 & 433269 & 380257 & 351835 \\
\hline $\begin{array}{l}\text { Officials of the local } \\
\text { government, persons }\end{array}$ & 98948 & 100582 & 100789 & 99783 & 99204 & 98117 & 97999 & 84548 & 83465 \\
\hline Civil servants, persons & 265315 & 278707 & 283408 & 279500 & 268104 & 274739 & 335270 & 295709 & 268370 \\
\hline $\begin{array}{l}\text { The share of local } \\
\text { government officials }\end{array}$ & 27,16 & 26,52 & 26,23 & 26,31 & 27,01 & 26,31 & 22,62 & 22,23 & 23,72 \\
\hline $\begin{array}{l}\text { The share of civil } \\
\text { servants }\end{array}$ & 72,84 & 73,48 & 73,77 & 73,69 & 72,99 & 73,69 & 77,38 & 77,77 & 76,28 \\
\hline $\begin{array}{l}\text { The average } \\
\text { expenditure per public } \\
\text { servant, thousand UAH }\end{array}$ & 20,43216 & 26,56151 & 24,87768 & 28,40478 & 31,08598 & 32,40669 & 29,5308 & 32,90909 & 40,50933 \\
\hline $\begin{array}{l}\text { Average expenditure } \\
\text { per civil servant staff of } \\
\text { ministries and other } \\
\text { central executive bodies } \\
\text { and subordinate } \\
\text { territorial bodies, } \\
\text { thousand UAH }\end{array}$ & 390,43 & 522,64 & 495,33 & 558,18 & 591,58 & 634,21 & 671,57 & 656,83 & 748,09 \\
\hline $\begin{array}{l}\text { Marginal costs per a } \\
\text { civil servant }\end{array}$ & $\cdots$ & 1,30 & 0,94 & 1,14 & 1,09 & 1,04 & 0,91 & 1,11 & 1,23 \\
\hline $\begin{array}{l}\text { Marginal costs per a } \\
\text { civil servant staff of } \\
\text { ministries and other } \\
\text { central executive bodies } \\
\text { and subordinate } \\
\text { territorial bodies }\end{array}$ & $\cdots$ & 1,34 & 0,95 & 1,13 & 1,06 & 1,07 & 1,06 & 0,98 & 1,14 \\
\hline $\begin{array}{l}\text { GDP growth, expressed } \\
\text { in US dollar terms per } \\
\text { capita }(\%) \text { previous } \\
\text { year })\end{array}$ & 33,2 & 26,8 & $-34,6$ & 16,8 & 20,1 & 8,0 & 4,5 & $-25,2$ & $-29,8$ \\
\hline Marginal GDP & $\ldots$ & 1,03 & 0,98 & 0,95 & 0,87 & 0,99 & 1,03 & 0,91 & 0,90 \\
\hline
\end{tabular}

Source: calculated by authors, based on data of State Treasury Service, State Statistic Service of Ukraine and National

Agency for State Service

\section{Discussion}

However, for economies such as the Ukrainian, the use of standard indicators is not always indicative because quantitative changes in welfare occur with a certain time lag. In this case, additional information can be given by alternative indicators that characterize the country's position in international rankings. It should be noted that the significance of such indicators is essential, because the basis of their calculations is not only static information about the countries surveyed, which is not always reliable, but estimates can be formed also using unofficial data.

One of the most informative rankings is the Index of Economic Freedom, which is calculated by the Heritage Foundation. The Index of Economic Freedom focuses on four key aspects of economic environment, which depend on government bureaucracy, namely the rule of law, the size of government, regulatory efficiency, and open markets. The indicator may range from 0 to 100 , and depending on the number of points a country can be qualified as free, mostly free, moderately free, mostly unfree, or repressed.

During the studied period, the economic freedom index fell from 51.5 in 2007 (Ukraine then belonged to the category of mostly unfree countries) to 45.8 in 2012, when Ukraine fell into the category of repressed. From 2009 to 2015, Ukraine was in the category of repressed (Table. 4). It should be noted that in 2014 Ukraine's index increased significantly compared to 2013, but in 2015 Ukraine lost its position again, indicating the low efficiency of government bureaucracy. 
Table 4. Ukraine's Position in the Ranking of Economic Freedom in 2007-2015

\begin{tabular}{lccccccccc}
\hline \multicolumn{1}{c}{ Indicators } & $\mathbf{2 0 0 7}$ & $\mathbf{2 0 0 8}$ & $\mathbf{2 0 0 9}$ & $\mathbf{2 0 1 0}$ & $\mathbf{2 0 1 1}$ & $\mathbf{2 0 1 2}$ & $\mathbf{2 0 1 3}$ & $\mathbf{2 0 1 4}$ & $\mathbf{2 0 1 5}$ \\
\hline Index of economic freedom & 51.5 & 51 & 48.8 & 46.4 & 45.8 & 46.1 & 46.3 & 49.3 & 46.9 \\
Fiscal freedom & 90,2 & 83,6 & 79 & 77 & 77,9 & 77,3 & 78,2 & 79 & 78,7 \\
Government spending & 53.2 & 43 & 39 & 41 & 32.9 & 29.4 & 28 & 37.5 & 28 \\
Freedom from corruption & 26 & 28 & 27 & 25 & 22 & 24 & 23 & 21,9 & 25 \\
Financial freedom & 50 & 50 & 50 & 30 & 30 & 30 & 30 & 30 & 30 \\
Property rights & 30 & 30 & 30 & 30 & 30 & 30 & 30 & 30 & 20 \\
\hline
\end{tabular}

Source: Heritage Foundation

In general, economic freedom is a fundamental right of every person to manage her/his own labor and property. In an economically free society, individuals are free to choose work, the production of goods, and investment costs any way that they want. These freedoms are supported and protected by the government. Based on the data presented in Table 4, economic freedom in Ukraine is practically nonexistent. This is due to the formation and development of modern Ukrainian bureaucracy and its fusion with large business interests. Specific to Ukrainian bureaucracy development is that in the early 1990's new political elite started to cooperate with big businesses. Clans began to form around influential leaders that controlled, and continue to control, administrative areas which are supported by the relevant financial and industrial groups. L. Solonko describes the result as a device of quasi-corporate groups who adapted the new regime and its formal institutions to their own business interests (Solonko, 2001).

In fact, a privatization of power has taken place, and bureaucracy, rather than enforces responding to the needs of the public, became a guardian of the interests of the ruling clans. Therefore, economic freedom in Ukraine has become a privilege for a narrow circle of Ukrainians. At the beginning of large-scale privatization, and especially in 1998, government bureaucracy began actively to make the transition to an elitist model of privatization, in which top officials transferred shares of state enterprises into the hands of individual businessmen, friends of the powerful, or their relatives, with the condition that they then follow the directions of the class of financial oligarchs. They financed election campaigns of government parties and individual candidates, they own the national TV channels, which then dispense filtered information according to the whims of their owners, and share profits with top government officials (Lanovoy, 2015). It is this situation that developed into one of the major failures of Ukrainian bureaucracy: bias and service to political leaders and big business owners. As a result, Ukraine is in the category of repressed states.

This negative assessment of the oligarch's role in Ukrainian politics and government bureaucracy does not mean that the oligarchs are socially unacceptable people. On the contrary, many of them are highly educated, but they are essentially hostages to their love of money and power, and as a result take actions that are self-serving and not beneficial for the nation. A peculiarity of the Ukrainian oligarch capital structure is its low efficiency, because it is not the result of hard ethical labor or business management, but of a property redistribution previously rendered. Oligarch capital does not generate capital gains, but increases due to semi-legal redistributions of financial flows through the banking system and access of the oligarchs to further government funds.

All oligarchs are basically the same, regardless of which party they support and what slogans they spout, which noble image to masquerade in. All of them are primarily interested in increasing their personal wealth and use the same method to do so: obtain access to power, use officials to lobby for financial preferences, acquire additional assets. There are no good or bad oligarchs, all of them being in government posts are essentially businessmen of the "wheeler-dealer" ilk and they continue to think of their wealth, not of the country. They know that they are in public office temporarily, do not plan to build a career there, and so are generally uninterested in effective work for the society they were elected or appointed to serve.

It should be noted that no matter the size of the bureaucracy and the amount of funds allocated for its maintenance, in terms of guarantees of property rights, according to the Index of Economic Freedom, during any period Ukraine did not have more than 30 points, and in 2015 it was even 20. According to the methodology of the Heritage Foundation, this means that property rights in Ukraine have little protection, the judicial system is inefficient and highly dependent on other branches of government, corruption is the norm, and there is a high risk of expropriation of property. This is then a situation where taxpayers' money is being sent to maintain a government bureaucracy which operates in reality to repress them and steal from them. A similar situation exists with the rate of freedom from corruption, when, during the studied period, it basically remained static, but correlated with the marginal costs of bureaucracy (Fig. 2). 


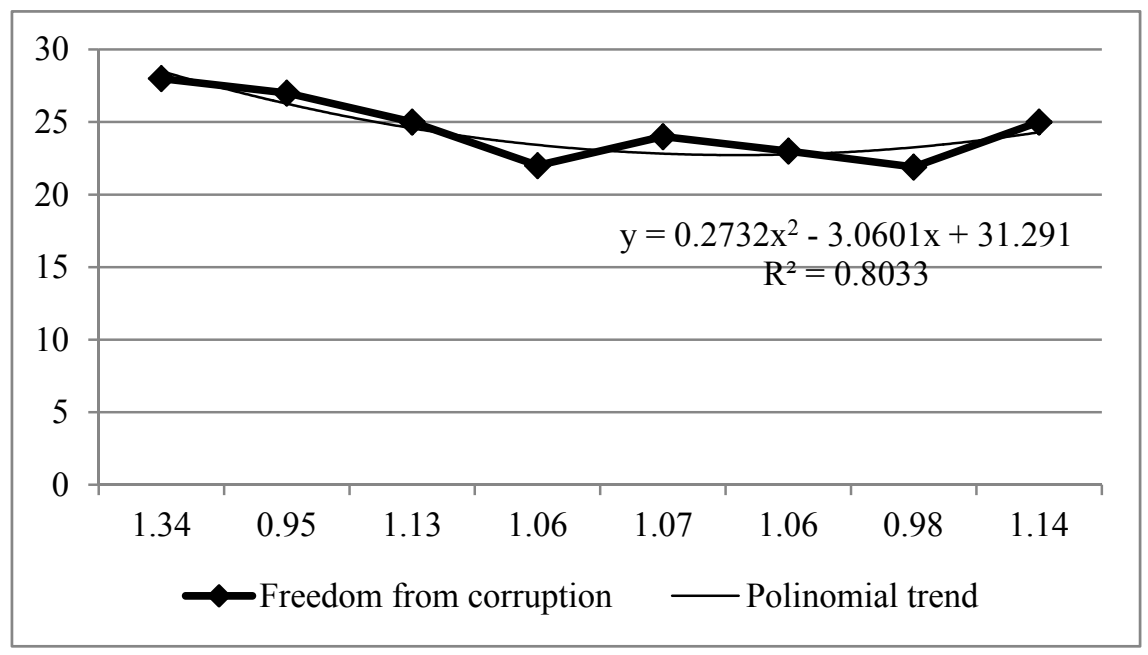

Figure 2. Correlation between Index of freedom from corruption and bureaucracy marginal costs in Ukraine

Source: created by authors

The coefficients in the equation in Fig. 2 show that if marginal costs of bureaucracy increase by 1, the freedom from corruption index decreases by 3 (negative trend). The corrupt officials in the government bureaucracy are oligarch's partners, they do not just support each other, they also feed from each other's power. If oligarchs were separated from government bureaucracy, the local officials would not have such high incomes, as reflected in the electronic declaration of income. Similarly, with an absence of loyal corrupt officials, oligarchs would not have access to public funds.

Corruption in the Ukrainian government is a dangerous phenomenon, not only because of the scale, but also because of the closed "corrupt official - oligarch" system, a prerequisite for the instability in the country. This explained the fact that opposition oligarchs supported events at the Maidan Revolution of Dignity, but this never meant that they were going to destroy systemic corruption (Tab. 5).

Table 5. Corruption Perception Index

\begin{tabular}{llllllllll}
\hline Indicators & $\mathbf{2 0 0 7}$ & $\mathbf{2 0 0 8}$ & $\mathbf{2 0 0 9}$ & $\mathbf{2 0 1 0}$ & $\mathbf{2 0 1 1}$ & $\mathbf{2 0 1 2}$ & $\mathbf{2 0 1 3}$ & $\mathbf{2 0 1 4}$ & $\mathbf{2 0 1 5}$ \\
\hline $\begin{array}{l}\text { Corruption } \\
\text { perception } \\
\text { index) } \\
\text { (rank/score) }\end{array}$ & $(118 / 27)$ & $(134 / 25)$ & $(146 / 22)$ & $(134 / 24)$ & $(152 / 23)$ & $(130 / 26)$ & $(130 / 25)$ & $(130 / 26)$ & $(130 / 27)$ \\
\hline
\end{tabular}

Source: Corruption perception index

According to the above corruption perception ranking, Ukraine's place in the ranking after the events of 2013 did not change, even more, the country has since worsened. Despite recent enactments of anti-corruption laws, tolerance to systemic corruption is maintained by oligarchs who now have access to power. In fact, these repressive mechanisms are likely a cover for the continuation of corrupt schemes, and tool for demonstrative punishment against those who object.

As examples from history show, repression alone is not enough. China, having the death penalty, has executed 200 officials convicted of bribery each year since 2000. Perhaps the problem is not in the degree of repressive legislation, but in the degree of openness of information which should be available and understandable to the average citizen.

An important component of the Index of Economic Freedom is the financial and fiscal freedom and government spending index (tab. 4). Ukraine's numbers in the fiscal freedom index do not have the highest values, but nevertheless tend to decrease due to rising marginal tax rates for personal income and the total tax burden due to increases in unjustified overpayments of income tax and non-return of VAT refunds. These trends do not contribute to confidence in the government by taxpayers.

The government expenditures index characterizes the efficiency of government bureaucracy. Unlike the components of guarantees of property rights, it has no clear quantitative restrictions and varies depending on the level of development. However, the low level of property rights protection and financial freedom, as is the case of Ukraine during the studied period, the indicator again reveals low efficiency in government bureaucracy.

The value of the component of financial freedom at 30 points means that the government maintains extensive activities. Also, it shows that the government owns or controls most financial institutions, whose activities are strictly limited. 
Moreover, most Ukrainian banks are directly or indirectly under the control of oligarchs, and associated with politicians. For example, "Privatbank" is owned by I. Kolomoiskiy and H. Boholubov, PUMB is owned by R. Akhmetov, "Credyt Dnipro" is owned by I. Pinchuck. Many banks are under the control of parliamentary deputies (former or current), for example, Diamantbank is owned by D. Zhvania, Tascombank is owned by S. Tihipko, "Fortuna Bank" is owned by S. Tyshchenko, "Klirynhovy Dim" is owned by Y. Liovochkin and I. Fursin. Even the current President of Ukraine indirectly owns a $60 \%$ share of the "International Investment Bank", while his political ally, current parliamentary deputy, I. Kononenko, owns a $15 \%$ share of this bank.

The absence of financial freedom is confirmed by the fact that the Ukrainian market is gradually being abandoned by foreign banks, leaving space for Russian banks. From 2009-2012, the retail bank market saw ING Bank, Home Credit Group, Credit Europe Bank, Societe Generale, Swedbank all depart. In 2012, German Commerzbank sold Forum Bank, while the owners of Erste Bank and Kievan Rus did the same, and Volksbank International Group simply vacated the market entirely.

In 2014-2015, most banks with foreign capital were offered for sale. The negative tendency is that banks with foreign capital are then replaced by oligarch-owned banks, which are concerned primarily about lending money to the businesses of their owners, the oligarchs. Financial pressure in the banking sector has not decreased in 2016, as evidenced, for example, by the withdrawal of Khreshchatyk Bank from the market, and Platinum Bank, which is barely surviving.

Additionally, indicators of public administration efficiency, which are annually published by the World Bank Group, were analyzed ${ }^{2}$ (Table 6).

Table 6. Indicators of Efficiency of Public Administration in Ukraine in 2007-2015, $(-2.5 \ldots+2.5)$

\begin{tabular}{llllllllll}
\hline Indicators & $\mathbf{2 0 0 7}$ & $\mathbf{2 0 0 8}$ & $\mathbf{2 0 0 9}$ & $\mathbf{2 0 1 0}$ & $\mathbf{2 0 1 1}$ & $\mathbf{2 0 1 2}$ & $\mathbf{2 0 1 3}$ & $\mathbf{2 0 1 4}$ & $\mathbf{2 0 1 5}$ \\
\hline Voice and accountability & 0.04 & 0.06 & 0.03 & -0.1 & -0.13 & -0.29 & -0.33 & -0.08 & -0.03 \\
Government effectiveness & -0.67 & -0.71 & -0.8 & -0.75 & -0.81 & -0.58 & -0.65 & -0.38 & -0.51 \\
Regulatory effectiveness & -0.42 & -0.52 & -0.57 & -0.52 & -0.61 & -0.61 & -0.64 & -0.63 & -0.58 \\
Rule of law & -0.74 & -0.69 & -0.77 & -0.81 & -0.83 & -0.79 & -0.83 & -0.79 & -0.80 \\
Control corruption & -0.74 & -0.79 & -1.01 & -0.98 & -1.00 & -1.03 & -1.09 & -1.00 & -0.98 \\
Political stability, no violence & 0.15 & 0.03 & -0.31 & -0.02 & -0.08 & -0.1 & -0.76 & -1.93 & -1.93 \\
\hline
\end{tabular}

Source: Worldwide Governance Indicators

The values range from " -2.5 " to " $+2.5 "$. According to the data presented in Table 6, significant changes in the rankings for Ukraine did not occur, except the indicator of political stability and violence, which deteriorated sharply in 2014 due to the outbreak of conflict in the Donbass. Indicators of voting rights and accountability (in 2015 there was a recovery to the level of 2013) and the efficiency of government (figure improved in 2014, but fell again in 2015) have not changed significantly over the last two years. From all present indicators, the values of the rule of law and control of corruption are the most troubling. Over the entire study period, they remained static and confirm again the low efficiency of law in Ukraine and the lack of tangible results in fighting corruption. For example, close to the Ukrainian rate of control of corruption stands Cambodia (-1.04), Cameroon (-1.03), Guinea (-0.97), Mauritania (-0.91), Nicaragua $(-0.87)$, Russia (-0.86). In terms of the rule of law, those close to Ukraine's ratings are Algeria (-0.83), Belarus $(-0.79)$, Lebanon (-0.79), Mali (-0.76), Pakistan (-0.79), Togo (-0.8). This demonstrates that the effectiveness of the Ukrainian government bureaucracy is at about the same level as those countries in Africa and Asia which were mentioned above.

In fact, in addition to direct budget expenditures for the maintenance of government bureaucracy, Ukrainian society annually loses much more because of corruption (Fig. 3).

\footnotetext{
${ }^{2}$ Worldwide Governance Indicators.-[Electronic source].-Available at: http://info.worldbank.org/governance/wgi/index.aspx\#home
} 


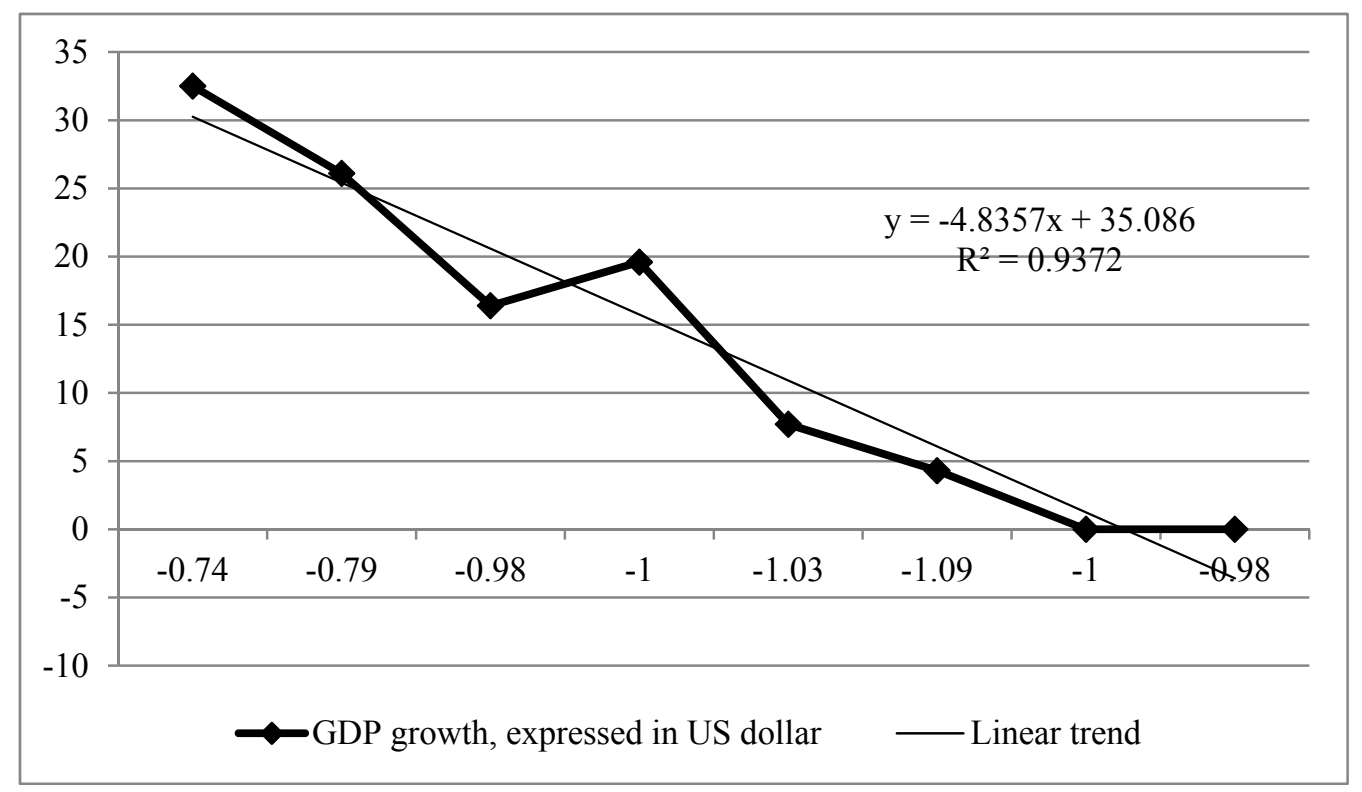

Figure 3. Correlation between GDP growth, the equivalent in USD and index of control of corruption in Ukraine Source: created by authors

A linear correlation exists among the studied parameters with a high coefficient of determination, which is reliable and coincidental. The equation coefficients show that an increase of 1 in the corruption control index means that Ukraine sees a $4.84 \%$ decrease in GDP in dollar terms. Based on the calculated elasticity, over the studied period Ukraine lost at least US\$ 3.751 billion GDP due to corruption. These losses of GDP represent lost benefits to the citizens of Ukraine, lost due to the support of corruption in the government bureaucracy.

\section{Acknowledgements}

The following conclusions are not to be seen as an exhaustive list, but as first steps to setting Ukraine on the path of economic freedom.

1. The government bureaucracy in Ukraine is grossly ineffective, and its cost to society, taking into account the loss of potential economic growth, is enormous. The existing bureaucratic-oligarchic union deprives the country of its future, does not promote the rule of law, and does not fight corruption. We often hear the opinion that corruption has become a Ukrainian national feature and therefore cannot be overcome. However, international experience shows New Zealand, Finland, and Singapore have all successfully overcome systemic corruption. It is not enough to adopt a number of laws, create agencies and bureaus to fight corruption. Rather, it is necessary to radically change the approach to the formation of government bureaucracy and control its activities.

2. Work in government bureaucracy must be conducted by professionals who want to develop professionally in this area. Therefore, they must attain good results in their duties of service. They must not have connections with business or related entities and must not act in the interests of any political oligarchic group. It is important to establish direct prohibitions for businessmen to work for the government or municipal authorities.

3. Information on management decisions by politicians and on all financial flows under the control of government bureaucracy must be made available to the public. The current business situation in Ukraine requires an inordinate amount of bureaucracy, which is used by corrupt officials to effectively control business markets and opportunities, forcing funds back into the hands of the oligarch masters. This cycle must be broken through sound deregulation and complete transparency of business/government interactions.

4. In cases of privatization, limits must be set prohibiting the sale of shares to one holder, thereby neutralizing oligarchic clan influence, and preventing the further creation of oligopolies.

\section{References}

Batrymenko, O. (2009). Development Trends of the Bureaucracy in Modern Social and Political Life. Vistnyk Kyivskoho natsionalnoho universytetu imeni Tarasa Shevchenka. Filisofiia. Politolohia, 91/93.

Caplan, B. (2007). The Myth of the Rational Voter. Princeton: Princeton University Press. 
Dollar, D., \& Kraay, A. (2003). Institutions, Trade and Growth, Journal of Monetary Economics, 50(1), $133-162$. https://doi.org/10.1016/S0304-3932(02)00206-4

Doroshko, M. S. (2008) Nomenclature: the Lead Tip of the Soviet Ukraine (1917-1938). Kyiv, Nika-Tsentr.

Evans, P., \& Rauch, J. E. (1999). Bureaucracy and Growth: A Cross-National Analysis of the Effects of "Weberian" State Structures of Economic Growth, American Sociological Review, 64(5), 748-765. https://doi.org/10.2307/2657374

Hall, R., \& Jones, C. (1999). Why Do Some Countries Produce So Much More Output per Worker than Others? Quarterly Journal of Economics, 114(1), 83-116. https://doi.org/10.1162/003355399555954

Kaufmann, D. (2004). Governance matters III. Policy Research Working paper No. 2312, World Bank.

Kaufmann, D., Kraay, A., \& Zoido-Lobaton, P. (1999). Aggregating Governance Indicators, World Bank Working Paper 2195.

Knack, S., \& Keefer, P. (1994). Institutions and Economic Performance: Cross Country Test Using Alternative Institutional Measures, IRIS Working Paper No. 109. University of Maryland.

Knack, S., Kugler, M., \& Manning, N. (2003). Second Generation Governance Indicators, International Review of Administrative Sciences, 69(3), 345-364. https://doi.org/10.1177/0020852303693004

Lanovoy V. (2015). The Bermuda Triangle of Theft. Ekonomitcheskaya Pravda.-[Electronic source].-Available at: http:/www.epravda.com.ua/rus/publications/2015/11/13/567057/

Monnier, F., \& Thuillier, G. (2010). Historie de la bureaucratie: veriteset fictions. Ed. Economica.

Murphy, K. M., Shleifer, A., \& Vishny, R. W. (1993). Why is rent-seeking so costly to growth? American Economic Review, 83(2), 409-414.

Public Sector Efficiency Evidence for New EU Member States and Emerging Markets 1 by António Afonso 2, 3, Ludger Schuknecht 3 and Vito Tanzi. WORKING PAPER SERIES NO. 581 / JANUARY 2006

Puhach, V. (2006). The Phenomenon of the Bureaucracy in Transition Society. Dissertation kand. poli. science. Kyiv.

Richardson, G. (2008). The Relationship Between Culture and Tax Evasion Across Countries: Additional Evidence and Extensions. Journal of International Accounting, Auditing and Taxation, 17(2), 67-78. https://doi.org/10.1016/j.intaccaudtax.2008.07.002

Rodrick, D. (1999). Institutions for High-Quality Growth: What they are and how to acquire them. IMF Conference on Second-Generation Reforms.

Rudolph, T. J. (2009). Political Trust, Ideology, and Public Support for Tax Cuts. Public Opinion Quarterly, 73(1), 144-158. https://doi.org/10.1093/poq/nfp012

Solonko L. (2001). Imperial Component of the Ukrainian Ideology and Post-Soviet Bureaucracy. Politicheskaya Mysl, $1 / 2,14-32$.

Tsapko, O. (2012). Scientific Theories on Bureaucracy in Modern Society. Philosophical and Methodological Problems, $2,20-24$.

Ungureanu, D. M. (2012). Science and Social Responsibility: the "Bureaucratic Wars" from Public Choice Theory, European Journal of Science and Theology, 8(1), 235-244.

Weber, M. (1922). Wirtschaft und Gesellschaft. Nach der ersten vollst. Ausgabe v. 1922. Tübingen, 650-678.

Weede, E. (1996). Legitimacy, Democracy and Comparative Economic Growth Reconsidered. European Sociological Review, 12(3), 217-225. https://doi.org/10.1093/oxfordjournals.esr.a018189

Williams, A. D., \& Siddique, A. (2007). The Use (and Abuse) of Governance Indicators in Economics: A Review, Economics of Governance, forthcoming.

Worldwide Governance Indicators.-[Electronic source].-Available at: http://info.worldbank.org/governance/wgi/index.aspx\#home

\section{Copyrights}

Copyright for this article is retained by the author(s), with first publication rights granted to the journal.

This is an open-access article distributed under the terms and conditions of the Creative Commons Attribution license which permits unrestricted use, distribution, and reproduction in any medium, provided the original work is properly cited. 